\title{
Exploring students' perception and efficiency of technology-mediated ESP teaching
}

\author{
Dinara G. Vasbieva - Nataliia V. Saienko
}

DOI: 10.18355/XL.2018.11.01XL.11

\begin{abstract}
The paper investigates students' perception and efficiency of using technology in language teaching and learning practices with a specific focus on ESP teaching at a non-linguistic higher school. The purpose of this study was to determine students' self-reported perception and efficiency of the technology supported English language learning environment through survey questionnaire and observation. The study was designed to test the hypothesis that technology-mediated language classroom can be effective provided that the students' attitudes to digital technology integration in the classroom teaching and learning are positive; learners' autonomy of study and motivation are enhanced and teacher-dominated lesson practices are reduced.
\end{abstract}

Key words: technology-mediated ESP teaching, learners' autonomy, digital technology integration, information and communication technology (ICT)

\section{Introduction}

The widespread growth of media and information technology has generated a process by which the remarkable changes have been made in the system of higher education over recent decades. Successful technology-mediated teaching turns out to have had a large effect on students' motivation and learning habits and emerging new models of pedagogy. Since information and communication technology (ICT) has transformed the landscape of education, the possibilities of learning and discovery have grown exponentially. Integration of ICT in today's classrooms and technologically savvy students has enhanced the promotion of 21 st century skills, such as interactive communication skills, interpersonal skills, technology literacy skills as well as language skills related to workplace needs.

It is clear that learning technology is put into practice by the educator when using certain methods, techniques and digital learning tools to help students have grasp of the course materials (Borisova et al., 2016a). Nowadays, most universities implement a competency-based approach by using active and interactive learning instructional strategies which include computer simulations, business meetings, roleplays, case studies, psychological and other training (Vasbieva, Kalugina, 2016). The combination of these techniques with students' self-study makes it possible to develop professional skills (Borisova et al., 2016b).

The subject matter of the present study is the process of teaching English for specific purposes to EFL students at a non-linguistic higher school.

The scope of the study is the investigation of students' perception and efficiency of technology-mediated ESP teaching.

The purpose of the research is to determine students' self-reported perception and efficiency of the technology supported English language learning environment through survey questionnaire and observation.

The present study was designed to:

- test the hypothesis that technology-mediated language classroom can be effective provided that the students' attitudes to digital technology integration in the classroom teaching and learning are positive

- assess the degree of learners' motivation and autonomy of study

XLinguae, Volume 11 Issue 1XL, January 2018, ISSN 1337-8384, eISSN 2453-711X 
- work out plan of actions towards efficient technology-mediated ESP teaching.

In accordance with the subject, purpose and hypothesis of the study, the research objectives are as follows:

- to determine, describe and justify the students' perception and efficiency of using technology in the English language learning environment

- to assess the degree of learners' motivation and autonomy of study in technology-enhanced classrooms

- to suggest courses of action to sort out the problem of effective ICT integration into teaching/learning.

\section{Literature Review}

The education system exists today under conditions where the culture of the society as a whole and its individual groups is determined to a large extent by information culture. It is a very multifaceted concept, which includes:

- understanding the capabilities of the modern information and communication technology (ICT)

- knowledge of basic approaches, principles and requirements for its development, as well as the ability to use computer tools for teaching, processing and transferring information (computer literacy)

- ability to work with any information

- knowledge and the development of certain skills in the use of distributed information resources

- use of ICT and computer facilities to solve production problems

- understanding the technology of developing and using modern computer-based learning tools

- ability to use search engines on the Internet and Web 2.0 technologies, to cope with the age of information, to evaluate obtained information critically, to create and publish information themselves, and to communicate information in the form of written reports or classroom presentations.

The development of computer technology and ICT has led to the emergence of the concept of an information society, that is, a society built on the basis of the collection, storage, distribution, and use of various information, ways of its processing, delivering and receiving.

In recent years, many researchers in the field of educational technology, psychology and philosophy have been focused on the informatization of the educational process at various stages of its development, and psychological and pedagogical substantiation of the possibilities of using information technologies in higher education (Talyzina, 1969; Gershunsky, 1987; Mashbits, 1988; Robert, 2004 and others).

Several studies, for instance Polat (2000), Vagramenko (2000), Laptev et al. (2002), Khutorskoy (2005), Khuziakhmetov, Gabdrakhmanova (2016), Khuziakhmetov, Nasibullov (2016), Kong, Kayumova, Zakirova (2017), Masalimova et al. (2017), Li, Pyrkova, Ryabova (2017) have been conducted on computer technology and ICT in education as a whole and EFL teaching in particular.

Nowadays, blended learning is one of the most important ways to organize an educational process using ICT. It has great potential to increase students' outcomes and create exciting new roles for teachers (Vasbieva, Klimova, 2015).

A growing body of literature has investigated the effectiveness of blended learning. In particular, it was found that blended learning is largely student-driven, provides them with satisfaction, forms and improves language skills, and develops critical thinking skills. Bendania (2011) revealed the relationship between students' positive attitudes towards blended learning and such factors as experience, 
confidence, joy, usefulness, desire to use ICT, motivation, and formation of ICT competence. He also studied the learning styles and students' satisfaction with English as a foreign language from the use of web resources. Students' positive attitudes to blended learning are explained by its numerous advantages such as its benefits, pleasure, accessibility, convenience, a large number of resources, etc. It is noted that the gender has some influence on the students' preferences in the learning style, but has nothing to do with their satisfaction with the use of web resources.

McCarthy and Murphy (2010) claim that learners show positive attitudes to blended learning, its aspects, simplicity, and contents.

Other researchers studied students' ICT competence, their interests in the use of the Internet. It was found that the more students participate in discussion online forums, the more they achieve in their learning, and the more positive their attitudes to blended learning (Chen, Peng \& Sun, 2010).

Students' attitudes to the three methods of teaching using ICT received much attention in even earlier studies (Edwards \& Fritz, 1997). The findings showed that the students found e-learning easy and interesting, and thanks to it they could get acquainted with new educational tools and apply them in practice. According to the participants of the study, the use of e-learning materials led to better results than faceto-face instructions. Other studies have clarified some additional factors that determine the effectiveness of using blended learning. Badawi (2009) argues that the use of e-learning depends on various factors. For example, the students' attitudes to elearning and their decision to use e-learning also depend on the influence of important people around them. At the same time, the availability of e-learning plays a significant role in the formation of a behavioral model regarding the use of e-learning.

Artino (2010) revealed the influence of such personal factors on the choice of the format of training for students as satisfaction and the ability to learn about new things from the Internet. Sauers and Walker (2004) found that the students, who were taught in the blended learning environment, indicated that such a course setting is more useful than face-to-face classroom activities.

Many Russian scientists also reported on the merits and importance of elearning (Satunina, 2006; Rubin, 2008; Aynutdinova, 2015; Evdokimova, 2007; Mironova, 2010 and others).

British methodologist Marsh (2012) and western scholars such as Brodsky (2003), Chapell (2001), Rutven-Stewart (2003), Hanson (2009), Brown (2006) pointed out the need for a competent approach to the development and introduction of e-learning courses in teaching English in order to form a student's positive attitude towards this type of learning using ICT.

Clearly, students like to use multimedia, but such technologies must be introduced properly and efficiently, in order to improve and maximize learning outcomes. On the other hand, some studies show that students experience anxiety and confusion when interacting with online materials (Baharun \& Porter, 2009; Mohr, Holtbrugge \& Berk, 2012).

\section{Methodology}

\subsection{Research Context and Participants}

The purpose of this research paper was to determine students' self-reported perception and efficiency of the technology-mediated ESP learning environment through survey questionnaire and observation.

A survey was used in order to get an insight into the students' attitudes to the use of ICT in ESP learning environment at a non-linguistic higher school. A questionnaire was developed by EFL teachers and distributed among first-year undergraduate students majoring in Economics and Finance, Management in Tourism and Hotel Business at the Financial University under the Government of the Russian 
Federation. They were chosen on a random basis. A total of 85 students took part in this study.

\subsection{Data Collection Procedure \& Questionnaire}

To carry out the research on students' perception of using technology in ESP classes, five research questions were formulated in one-page research questionnaire for this study:

1. Do you prefer an ICT-integrated ESP classroom?

2. Does technology-enhanced language learning environment engage and motivate you to study in a new learning situation?

3. Do you notice technology-enhanced teaching and learning change the teachers' role from a dominator of knowledge to a facilitator of knowledge?

4. What's your perception of using technology in language learning environment?

5. What additional suggestions would you make?

They were multiple choice questions (MCQ) as well as a question asking for short suggestions, offering the respondents a free reign. The students willingly responded to the questionnaire, and most of them put forward some admirable suggestions. The questionnaire for this survey was designed to determine students' self-reported perception and efficiency of technology-supported learning.

\subsection{Research Stages}

The research was conducted in three stages.

The first stage involved: studying previous research; defining the subject matter, scope and purpose of the research; developing a hypothesis; formulating research objectives; defining methods appropriate to the purpose and objectives of the study; describing and justifying the students' perception and efficiency of using technology in ESP learning environment.

In the second stage, we conducted the survey data analysis to gain an insight into EFL students' perception of using technology in English classes at a nonlinguistic higher school. We assessed the degree of learners' motivation and autonomy of study in technology-enhanced classrooms. The efficiency of using technology in language teaching and learning practices with a specific focus on ESP teaching at a non-linguistic higher school was theoretically justified and assessed.

The third stage included the courses of action to sort out the problem of effective ICT integration into teaching/learning; systematization and analysis of the results obtained; drawing conclusions.

\section{Limitations of the Study}

The present study involved only a questionnaire as a research instrument. The limited time allotted for this research did not allow for such deep investigation to occur. However, we are going to continue this project in future research by delving deeply into the real effects by conducting an experimental study with a control group and an experimental group, a method that is likely to measure the real outcomes of the efficiency of the technology-mediated ESP teaching at a non-linguistic higher school.

\section{Results and Discussion}

This study administers both quantitative and qualitative data analysis methods. From the collected data of questionnaire, the percentage of respondents offering the same answer was calculated in Microsoft Excel to produce research findings. The findings of the research were interpreted both quantitatively and qualitatively. The figures below illustrate the EFL students' answers to some of the questions which in our opinion best reveal their perceptions of technology integration into English language classrooms. 


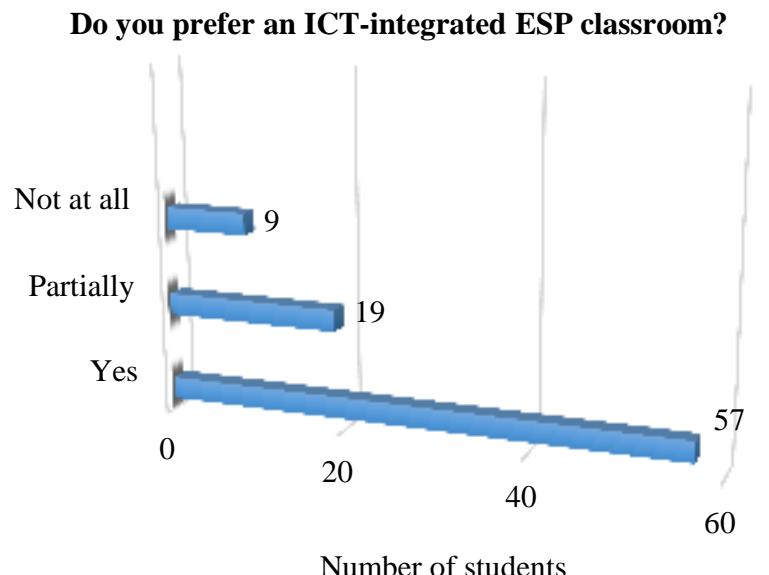

Figure 1: Students' answers to Question 1

Figure 1 depicts the participants' perceptions of using digital learning tools, such as computers and handheld devices in the ESP learning environment. The respondents overwhelmingly answered positively $(67+22) \%$ showing the strong support with reference to their ties and attitude to digital technology integration into the English language classroom. 11\% of the students gave negative answers because of the lack of instructional technology skills and ignorance of the use of technology in the learning process. Students' negative attitudes to technology-enhanced English classes result from the fact that they are less «computer savvy» and were, therefore, less likely to welcome and adapt to technology than those with positive attitudes. (Harrison, Rainer, 1992). So, suggestive here is empowering students to be digitally literate to advance learning in the digital age.

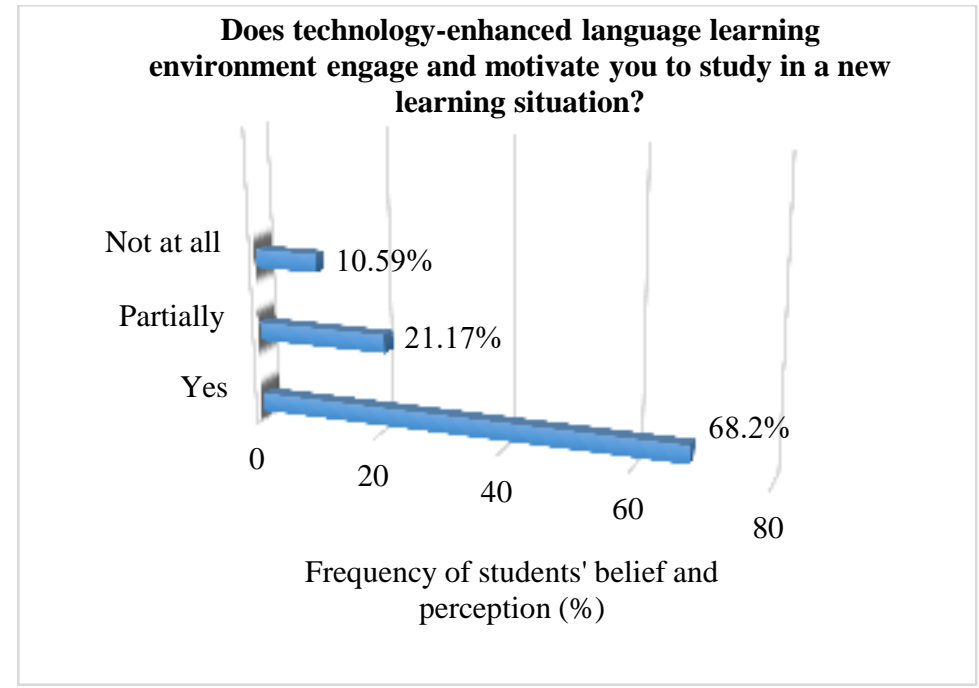

Figure 2: Students' answers to Question 2

XLinguae, Volume 11 Issue 1XL, January 2018, ISSN 1337-8384, eISSN 2453-711X 
As can be seen from Figure 2, the second question was asked to find out the efficiency and relevance of technology-integrated ESP classes encouraging learners to study in a new learning situation. Surprisingly, most of the students $(68.2 \%+21.17 \%=89.9 \%)$ believe that technology-enhanced teaching approach creates "a new learning situation" which reveals their real perceptions and efficiency of the digital technology-enhanced teaching and learning portfolio. The result of this hypothesis infers EFL students' positive perceptions of technology-enhanced teaching practices. It assures that technology-supported learning situation attracts students' attention and promote their immersion in the language learning activities more than conventional pedagogy.

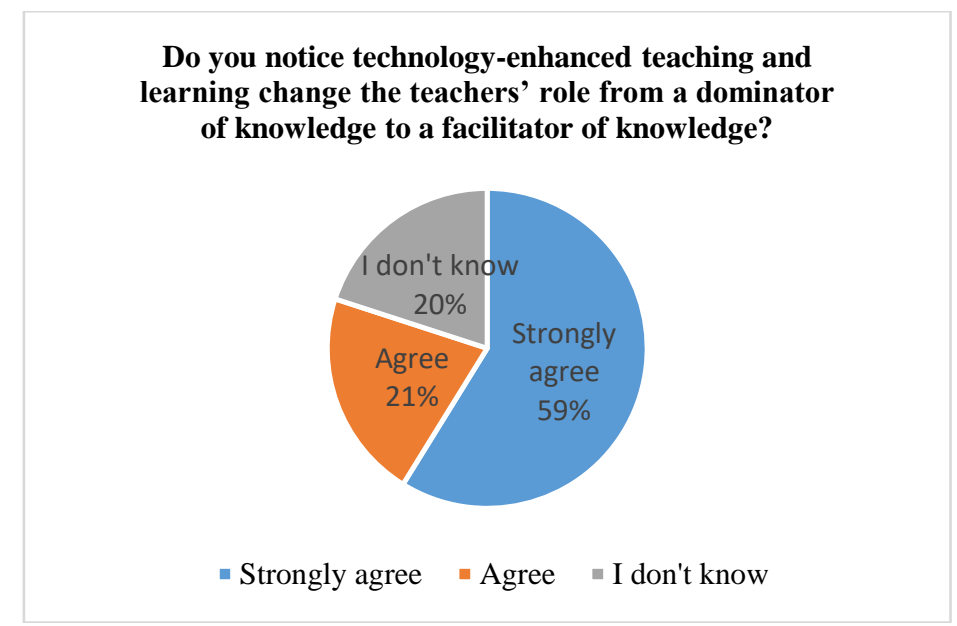

\section{Figure 3: Students' answers to Question 3}

As shown in Figure 3, the third question seeks to capture students' opinion regarding the teachers' role in a technology-mediated 21 st-century learning situation. Data analysis reflects that technology-enhanced teaching drives the changing trajectory of the teachers' role from a dominator of knowledge to a facilitator. The participants $(59 \%+21 \%=80 \%)$ agreed that technology integration into EFL classes facilitates a higher degree of teacher-student interaction and collaboration. Consequently, it develops learners' ample chances to work and reflect more than what they did in the traditional lesson. So, technology-enhanced teaching practice enhances learners' autonomy of study and at the same time, reduces teacher-dominated lesson practices. On the other hand, the presence of $2 \%$ students' unintelligibility of technology use in learning process draws a subtle line of attention to the education managers to mitigate students' concern to enhance 'digital literacy' as 21 st-century skills.

The fourth question was designed to explore students' self-reported assertion and perception of ICT-integrated teaching and learning. Table 1 shows students' responses to this question.

Table 1: Students' perceptions of using technology in language learning environment

\begin{tabular}{cccc}
\hline & Options & Answer & $\begin{array}{c}\text { Percentage } \\
(\%)\end{array}$ \\
\hline a) & $\begin{array}{l}\text { Technology-integrated ESP classroom ensures a } \\
\text { high degree of interaction }\end{array}$ & 51 & 75 \\
b) & Technology-mediated instructional strategies & 55 & 81
\end{tabular}


develop a learner-centred approach

c) Technology-enhanced learning environment can be seen as troublesome and time-consuming

d) ICT fosters and develops students' autonomy in learning languages and skills that can be applied to self-directed learning

e) I cannot say for certain if technology should be integrated into ESP classrooms

f) Web-based teaching and learning materials enhance students' knowledge and skills

The respondents (average approx. 80\%) as digital natives admit that technology-assisted classroom teaching practices to promote the EFL learners' autonomy needed for their real-life contexts. Using ICT makes teaching learnercentered by encouraging students' self-directed learning autonomy, promoting a higher degree of teacher-student interaction as well as Web-based teaching and learning materials expand students' knowledge. Apart from this, some students support the view that incorporating technology into the classroom has proven to be too time-consuming and troublesome. The education providers should take into account the respondents negative concern to implement technology in ESP teaching/learning practices.

As shown in Table 2 covering the fifth question, the participants were offered to express their own favorable or unfavorable perception or reflections regarding technology in teaching. The responses reflect the real perceptions of the students representing an average rate of $69 \%$. Most importantly, a contributing number of participants $85 \%$ suggested that EFL students training needs technologybased instruction and appropriate evaluation techniques that are in line with the methods of instruction, objectives and the technology, and $63 \%$ of them were disappointed with the fact that the entire generation of cutting-age technology is not usable in all the classrooms because of restriction of Wi-Fi.

Table 2: Suggestions \& Hints from data analysis

\begin{tabular}{llcc}
\hline № & \multicolumn{1}{c}{ Suggestions/Hints } & Respondents & $\begin{array}{c}\text { Percentage } \\
(\%)\end{array}$ \\
\hline 1. $\begin{array}{l}\text { The entire generation of cutting-age } \\
\text { technology is not usable in all the } \\
\text { classrooms because of restriction of Wi-Fi. }\end{array}$ & 43 & 63 \\
2. Sometimes technical problems prevent \\
$\begin{array}{l}\text { lesson progress. } \\
\text { All the classrooms need to be equipped } \\
\text { with smart technology and digital solutions } \\
\text { for demonstrating presentations. }\end{array}$ & 45 & 66 \\
Internet connection may be inconsistent \\
$\begin{array}{l}\text { and/or slow. } \\
\text { EFL students training needs technology- } \\
\text { based instruction and appropriate } \\
\text { evaluation techniques that are in line with } \\
\text { the methods of instruction, objectives and } \\
\text { the technology. }\end{array}$
\end{tabular}

XLinguae, Volume 11 Issue 1XL, January 2018, ISSN 1337-8384, eISSN 2453-711X 


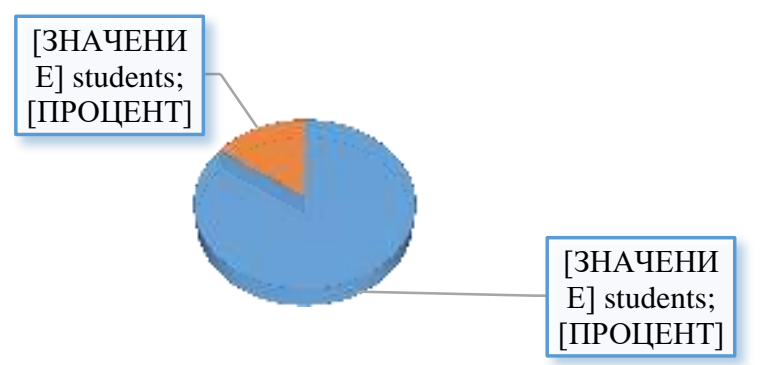

Students' positive perception $\quad$ Students' negative perception

\section{Figure 4: Students' perception of technology-mediated ESP teaching}

This study through data analysis seeks to sort out consistent and inconsistent issues relating to students' perceptions and efficiency of technology integration into ESP classroom. Figure 4 illustrates that about $85 \%$ of students demonstrate a positive attitude to technology-enhanced language learning environment proving the effectiveness of technology-mediated learning. ICTs have great potentials for knowledge dissemination from teaching staff to students. Apparently, analytical data findings provide insight into the role of technology-enhanced teaching-learning situation in motivating students to immerse in learning more than traditional pedagogy. Importantly, data analysis revealed that to a greater or lesser extent, lack of technology literacy impacts students' belief and perception regarding technology integration into the classroom. It can also be noted that the data analysis helped uncover the following challenges of integrating digital technology into teaching/learning:

- $\quad$ students' lack of technology literacy. Approximately $15 \%$ of students (13 out of 85 students) demonstrated negative perception towards technologyenhanced ESP classroom because of lack of technology literacy as well as ignorance of technology application in the classroom and their personal learning habits (Fig. 4).

- technical problems. They hinder the technology-supported classroom portfolio and influence students' belief and perception adversely.

- inadequate classroom facilities. $63 \%$ of the participants expressed disappointment at the fact that the entire generation of cutting-age technology is not usable in all the classrooms because of restriction of WiFi (Table 2). It also requires classroom to be equipped with smart technology and digital solutions for demonstrating presentations. Clearly, inadequate classroom tools to support learning/teaching can seriously limit the use of technology by teachers and students. Limited resources definitely result adversely in technology-enhanced learning activities.

The present findings might suggest several courses of action in order to solve the problem of effective ICT integration into teaching/learning:

- technology literacy training. To empower students in the digital age, digital or technology literacy skills and knowledge might be obtained through training on technology application in learning and teaching. If students are technology savvy, they will be motivated, and it will enhance their $21 \mathrm{st}-$ century qualifications.

- technology-equipped classroom. Language classrooms are to be wired with the Internet and cutting-age technologies (computers, interactive whiteboard, internet connectivity, TV and others) and be useable in all the classrooms without any restriction of Wi-Fi. Moreover, university 
authorities should develop a full-fledged instructional technology based lab with the Internet facilities.

- imparting technology skills to change students' perception through effective technology-integrated ESP curriculum, which is learner-centered and aimed at self-directed learning. Participants with negative perceptions were less skilled in technology use. The successful use and integration of technology into classroom largely depend on students' attitudes and beliefs. Changing individuals' negative perceptions into positive is an essential need to increase literacy skills. Accordingly, "Such attitudes are developed when (they) are sufficiently comfortable with technology and are knowledgeable about its use" (Khan, Hasan, \& Clement, 2012).

- $\quad$ troubleshooting management. Technical problems can be overcome through troubleshooting management by providing technical expert/support. Technology-mediated teaching can bring benefits to both teachers and students if they have the skills to apply it properly.

\section{Conclusion}

Thus the significance of this study stems from the idea that knowing students' opinions and views regarding technology-mediated ESP classes helps educators assess the efficiency of teaching/learning process. Besides, data analysis and research findings may contribute to the effective and successful ICT-enhanced language learning program by exploring students' perception and efficiency of technology-enhanced ESP learning environment. The findings revealed that EFL students demonstrated positive attitudes to the technology integration into their learning practices, which captivate their interest, increase their personal discovery, generate their enthusiasm and the desire to learn thereby instilling an interest from within to improve their motivation into learning engagement more than traditional pedagogy (Vasbieva, 2014). Interestingly, $80 \%$ of the students think that ICTenhanced teaching accelerates task-based learner-centric practices by replacing teacher-dominated lessons, increasing self-directed learning and autonomy, facilitating positive teacher-student interactions and promoting collaborative learning. The students identified technology as an effective educational tool that motivates them into a new situation and maximizes language learning acquisition. In addition, the findings of this study will shed useful light on the ELT experts, ESL/EFL teachers, students, curriculum designers. Our investigations into this area are still ongoing. This research has thrown up many questions in need of further examination of the effectiveness of technology-enhanced ESP teaching and learning.

\section{Acknowledgments}

The work is performed according to the Program of Development of Federal StateFunded Educational Institution of Higher Education "Financial University under the Government of the Russian Federation" for 2020.

\section{Bibliographic references}

ARTINO, A.R. 2010. Online or face to face learning? Exploring the personal factors that predict students' choice of instructional format. Internet and Higher Education, vol. 13, pp. 272-276. Available online: http://dx.doi.org/10.1016/j.iheduc.2010.07.005 AYNUTDINOVA, I.N. 2015. Burning issues of using blended learning in EFL teaching in a non-linguistic higher school. Society: sociology, psychology, pedagogy, n. 6, pp. 74-77. ISSN 2221-2795.

BAHARUN, N. - PORTER, A. 2009. Teaching statistics using a blended approach: integrating technology-based resources // Same Places, Different Spaces. Proceedings. 
Auckland: Ascilite, pp. 40-48. Available online: http://ascilite.org/conferences/auckland09/procs/baharun.pdf

BENDANIA, A. 2011. Teaching and learning online: King Fahd University of Petroleum and Minerals (KFUPM) Saudi Arabia, case study. International Journal of Arts and Sciences, vol. 4, n. 8, pp. 223-241. ISSN 1944-6934.

BIROVA, J. - KLIMOVA, I.I. - KALUGINA, O. 2016. Some critics on language education assessment. Mathematics Education, vol. 11, n. 7, pp. 2470-2482. ISSN 2468-4945.

BRODSKY, M. 2003. E-learning Trends, Today and Beyond. Learning and Training Innovations Magazine. Available online: http://www.elearningmag.com/ltimagazine/article/articleDetail.jsp?id=56219

BROWN, A. 2006. Technology-enhanced learning: strengthening links with practitioners. 12th International Conference on Technology Supported Learning and Training. Book of abstracts. Berlin, p. 36. Available online: https://icwesecretariat.com/oeb/uploads/OEB-BoA2006-Example.pdf

EDWARDS C. - FRITZ J. 1997. Evaluation of three online delivery approaches. Proceedings of the Mid-South Instructional Technology Conference, vol. 4, p. 16. ISBN 430516

EVDOKIMOVA, M.G. 2007. Foreign language teaching on the basis of information and communication technology (Technical University, English). diss ... Doct. of Pedagogy. Moscow.

GERSHUNSKY, B.C. 1987. Computerisation in education: Problems and perspectives. Moscow: Pedagogy. 265 p.

HANSON, J. 2009. Displaced but not replaced: the impact of e-learning on academic identities in higher education. Teaching in Higher Education, vol. 14, n. 5, pp. 553564. ISSN 1356-2517.

MASHBITS, E.I. 1988. Psychological and pedagogical issues of computer-based teaching. Moscow: Pedagogy. 191 p.

McCARTHY, M.A. - MURPHY, E.A. 2010. Blended learning: Beyond initial uses to helping to solve real-world academic problems. Journal of College Education \& Learning, vol. 7, n. 6, pp. 67-70.

MIRONOVA, L.I. 2010. Electronic educational resourses as a means of implementing educational technology at a higher school. Ekaterinburg: Ural State University. 196 p.

KALUGINA, O.A. 2016. Development of students' professional communicative competence in an economic higher school. In: XLinguae, vol. 9, n. 4, pp: $37-45$. ISSN 1337-8393.

KHAN, S. H. - HASAN, M. - CLEMENT, C. K. 2012. Barriers to the introduction of ICT into education in developing countries: the example of Bangladesh. International Journal of Instruction, vol. 5, n. 2, pp. 61-80. ISSN 1694-609X.

KHUTORSKOY, A.V. 2005. Is the modernisation of education an innovative process? Eidos. Available online: http://www.eidos.ru/journal/

KHUZIAKHMETOV, A.N. - GABDRAKHMANOVA, R.G. 2016. Creativity in joint activity of teacher and student in the learning process. In: IEJME - Mathematics Education, vol. 11, n. 4, pp. 735-745. ISSN 2468-4945

KHUZIAKHMETOV, A.N. - NASIBULLOV, R.R. 2016. Dialectics of correlation of the school student personality socialization and individualization in pedagogical theory and practice. In: IEJME - Mathematics Education, vol. 11, n. 4, pp. 475-487. ISSN 2468-4945

KONG, Y. - KAYUMOVA, L.R. - ZAKIROVA, V.G. 2017. Simulation Technologies in Preparing Teachers to Deal with Risks. In: Eurasia Journal of Mathematics, Science and Technology Education, vol. 13, n. 8, pp. 4753-4763. ISSN: $13058215,13058223$.

LAPTEV, V.V. - KONDRATEV, A.S. - KHODANOVICH, A.I. 2002. Tendencies of development and priority directions of education informatisation in the modern 
period. Education and culture of North-West Russia, vol.7, pp. 15-23. ISBN 5-80640574-5.

LI, N. - PYRKOVA, K.V. - RYABOVA, T.V. 2017. Teaching Communication Skills and Decision-Making to University Students. In: EURASIA Journal of Mathematics, Science and Technology Education, vol. 13, n. 8, pp. 4715-4723. MASALIMOVA, A.R. - LEVINA, E.Y. - PLATONOVA, R.I. - YAKUBENKO, K.Yu. - MAMITOVA, N.V. - ARZUMANOVA, L.L. - GREBENNIKOV, V.V. MARCHUK, N.N. 2017. Cognitive Simulation as Integrated Innovative Technology in Teaching of Social and Humanitarian Disciplines. In: Eurasia Journal of Mathematics, Science and Technology Education, vol. 13, n. 8, pp. 4915-4928.

MOHR, A.T. - HOLTBRUGGE, D. - BERK, N. 2012. Learning style preferences and the perceived usefulness of e-learning. Teaching in Higher Education, vol. 17, n. 3, pp. 309-322. Available online: http://dx.doi.org/10.1080/13562517.2011.640999

POLAT, E.S. 2000. New pedagogical and information technologies. Foreign languages for schools, n. 2, pp. 3-10. ISSN 0130-6073.

ROBERT, I.V. - POLYAKOV, V.A. 2004. Major directions of research into informatization of education. Moscow: Education and Information Science.

Sauers, D. - Walker, R.C. 2004. A comparison of traditional and technology-assisted instructional methods in the business communication classroom // Business and Professional Communication Quarterly, vol. 67, n. 4, pp. 430-442. Available online: http://dx.doi.org/10.1177/1080569904271030

TALYZINA, N.F. 1969. Theoretical issues of programmed teaching. Moscow: Pedagogy. $133 \mathrm{p}$.

TSVETKOVA, M.I. The Speed Reading is in Disrepute: Advantages of Slow Reading for the Information Equilibrium. European Journal of Contemporary Education, 2017, 6(3): 593-603. DOI: 10.13187/ejced.2017.3.593

VAGRAMENKO, A.YA. 2000. Information technologies and modernisation of education. Pedagogical Information Science, n. 2, pp. 3-10. ISSN 2070-9013.

VASBIEVA, D.G. 2014. A Lean Approach as a Means of Achieving Communicative Competence. XLinguae, vol. 7, n. 4, pp.75 -82. ISSN 1337-8384.

VASBIEVA, D.G. - KALUGINA, O.A. 2016. An Analysis of Students' Intercultural Competence Levels in a Non-Linguistic Higher School. In: XLinguae, vol. 9, n. 3, pp.58-69. ISSN 1337-8393.

VASBIEVA, D. G. - KLIMOVA, I. I. 2015. Transformational potential of blended learning to personalize foreign language teaching in a non-linguistic higher school. XLinguae, vol. 8, n. 1, pp. 2-10.

Words: 4688

Characters: 32047 (17,80 standard pages)

Assoc. Prof. Dinara G. Vasbieva, PhD

Department of Foreign Languages

Financial University under the Government of the Russian Federation

Leningradsky prospect 49, 125993 Moscow

Russia

dinara-va@list.ru

Prof. Nataliia V. Saienko, D.Sc. (Pedagogy)

Department of Foreign Languages

Kharkiv National Automobile and Highway University

25 Yaroslav Mudry Str. , 61002 Kharkiv

Ukraine

saienkonv@ukr.net

XLinguae, Volume 11 Issue 1XL, January 2018, ISSN 1337-8384, eISSN 2453-711X 